\title{
Analysis of the Medicinal Assortment as a Factor of Increasing the Competitiveness of Organizations in the Pharmacy Market of the Region
}

\author{
Tatyana I. Okonenko 1[ORCID 0000-0002-7431-3777],

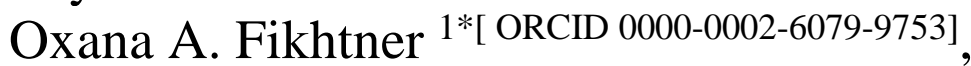 \\ Galina A. Antropova 1[ORCID 0000-0002-1317-7513]
}

\author{
${ }^{l}$ Yaroslav-the-Wise Novgorod State University, Veliky Novgorod, Russia \\ Oxana.Fikhtner@novsu.ru
}

\begin{abstract}
In the pharmaceutical market, there is fierce competition in its retail segment. In such a situation, the growth of competition between pharmacy organizations forces us to make adjustments to the assortment policy, which can affect the competitive position of an individual pharmacy in the region. The authors see the purpose of the study in assessing the state and level of competition in the Novgorod region pharmacy market in order to identify the organizational and financial conditions for the development of the drug assortment and the possibilities of pharmaceutical care for patients with ophthalmic pathology. To solve the tasks at hand, regulatory materials were studied, sales of ophthalmological drugs in the retail segment of the regional pharmaceutical market were considered. The ABC-analysis of the sales of medicinal products used in ophthalmology was carried out using statistical data from Novgorod pharmacy enterprises for the period 2016-2018. Analysis of the range of ophthalmic drugs showed that the formation of the range is not so much an economic task as a social one, since drugs are in demand by all residents of the region. Reduction or rejection of unprofitable assortment positions in pharmacies is unacceptable. However, in order to ensure a competitive position and the possibility of an effective (break-even) pharmacy business, it is necessary to use various tools for increasing competitiveness, ranging from a wide range, maintaining a stable presence in the range of drugs from the Vital and Essential Drugs List, using marketing tools to stimulate consumer demand and maintain consumer loyalty at a high level. Since pharmacies are a socially significant aspect of the population's life support system, it is important to attract state resources (adequate regulatory framework, regional and federal support programs, including financial) to implement a long-term strategy for the socio-economic development of the Russian Federation and sustainable territorial development of the Novgorod region.
\end{abstract}

Keywords: competitiveness, ABC-analysis, the assortment policy, pharmacy market, regional economy

\section{INTRODUCTION}

Competitiveness is the ability of a market entity to be more successful in comparison with similar market agents in a specific market at a specific time to achieve the same goal, the best use of labor, material, money and maximum financial performance.

The level of competition is growing rapidly in all market segments, among which the pharmaceutical sector is one of the most profitable [1]. The pharmacy business is also fiercely competitive due to its high profitability and the ability of enterprises to operate on a franchise basis. In addition, the number of competitors is growing due to the networkization and concentration of this segment, as well as due to the use of electronic drug trade mechanisms [2-5].

Many factors influence the level of competitiveness of an individual pharmaceutical company. Some of these factors are due to global trends in the development of the pharmaceutical industry, while others depend on the country and the 
characteristics of its pharmaceutical industry [6]. For example, despite the attractiveness of the pharmaceutical market for business, the number of pharmacies in Germany is decreasing [7].

Since 2017, Russia has seen more than $15 \%$ growth in the number of pharmaceutical outlets. The increase in their number is explained by the possibility of obtaining additional profit due to the growth in the cost of medicines and their wide range. A large number of assortment positions of drugs is explained by the fact that in the pharmaceutical market, medicinal drugs (hereinafter - MD) of one international nonproprietary name (hereinafter - INN) have several trade names, depending on the manufacturer. However, over the past five years, the growth of the national pharmaceutical market has slowed down 6 times. The market growth in 2017 compared to 2016 was $8.2 \%$, and in 2018 its volume reached 1.7 trillion rubles, i.e. increased by only $1.8 \%$ compared to 2017 , and taking into account inflation, the market did not grow at all in 2018 [8].

In such a situation, the growth of competition between pharmacy organizations forces us to make adjustments to the assortment policy, redistribute funds between different groups of drugs in order to minimize risks [9-10].

Of course, the quality of medicinal products and the services offered are of great importance in the competitive struggle, but the most relevant in the current competitive environment is a well-formed assortment. Assortment management is the basis of many management decisions [11]. Therefore, the study and analysis of the assortment is a paramount task for any enterprise, especially in the pharmacy segment. ABC-analysis as a method of management accounting in a pharmacy chain is used to rank positions in the existing drug assortment by cost level, while a relatively small number of reasons are responsible for most of the possible results, i.e. only $20 \%$ of positions provide $80 \%$ of the result of highranking and low-ranking positions.

Thus, the problem of using ABC-analysis of medicinal products to identify opportunities for competitive growth of the regional pharmaceutical market (its pharmacy segment) in order to identify strategic priorities for the territorial development of the Novgorod region appears to be urgent.

\section{MATERIALS AND METHODS}

The aim of the study is to assess the state and level of competition in the Novgorod region pharmacy market, to identify the organizational and financial conditions for the development of the drug assortment and the possibilities of pharmaceutical care for patients with ophthalmic pathology.

Research objectives:

- to study the main statistical indicators of the socio-economic development of the Novgorod region, necessary for the said analysis (the number of pharmacy organizations, average per capita income of residents of the region, etc.);

- based on the clinical and economic analysis (ABC-analysis) of the ophthalmological assortment of pharmacy organizations in the region and its structure, to study the competitive situation in the regional pharmacy market;

- to identify the sources of growth in the competitiveness of pharmacy enterprises in the region, capable of providing a high level and quality of life for the population of the Novgorod region.

The authors focused on the time period of 20162018, since from 2019, with the arrival of COVID19, there has been a transformation of the medical services market, in particular, the pharmaceutical segment. Therefore, for the accuracy of the analysis, the authors limited the analyzed period.

To solve the tasks at hand, federal and regional regulatory materials were studied: Order of the Government of the Russian Federation of 1996 No. 1063-r "On social standards and norms", the State Register of Medicines for the selection of drugs included in the Vital and Essential Drugs (hereinafter - VED) List, statistics from the Federal State Statistics Service of the Russian Federation.

The sales of ophthalmic drugs in the retail segment of the regional pharmaceutical market are considered. Analyzed the turnover in rubles, as well as the turnover by commodity items, commodity categories [12-13]. Based on the ABC-analysis of the assortment of ophthalmic medicinal products of Novgorod pharmacy enterprises for the period 20162018, reasoned conclusions were made on ways to increase the competitiveness of the regional pharmaceutical market.

\section{RESULTS}

Pharmaceutical assistance to the population of the Novgorod region is provided by 276 pharmacy enterprises. During 2015-2018 their number 
remained virtually unchanged. There are 114 pharmacies in Veliky Novgorod $(42 \%$ of all pharmacy enterprises), which is 6 times higher than the standard established by the Order of the Government of the Russian Federation of 1996 No. 1063-r "On social standards and norms" for cities with a population of over 100 thousand to 500 thousand people [14]. Consequently, the competition in the pharmaceutical market in Veliky Novgorod is great.

In the period of 2016-2018 the growth of the pharmaceutical market was mainly due to the retail sales segment. Using data from the Federal State Statistics Service of the Russian Federation [15], it was revealed that there is no growth in real incomes of the population in the Novgorod region. According to the indicator of average per capita money income of the population in 2015, the Novgorod Region was in 8th place among 12 subjects of the Northwestern Federal District of the Russian Federation. This income was 25773 rubles, which is lower than the average per capita income of the population of the Northwestern Federal District of the Russian Federation as a whole (34595 rubles). In 2018, the income of residents of the region slightly decreased (25198 rubles), and according to this indicator, the region was in 11th place in the district. A similar indicator in the Northwestern Federal District of the Russian Federation was 32609 rubles [15]. This fact did not allow and does not allow for predicting an increase in the cost of medicines.

The results of the ABC-analysis of a group of ophthalmic medicinal products purchased by the pharmacy chain of the Novgorod region are presented in Table 1.

The results of inclusion in the groups fit into generally accepted recommendations. The range of ophthalmic products has been practically stable for three years. In 2017, 3 drugs for the treatment of glaucoma appeared in group $\mathrm{A}$, which came here from group B - INN Dorozolamide, INN Brinzolamide + Timolol, INN Betaxolol. In 2018, Hydrocortisone and the antiglaucoma drug Betaxolol moved from Group A to Group B, and Chloramphenicol, Dorzolamide + Timolol appeared in Group A. An interesting fact is that during this period in the Novgorod region no adverse events were recorded for drugs of this group [16].

Further, the authors carried out an ABC-analysis of a group of ophthalmic medicinal products purchased by a single pharmacy, the results of which are presented in Table 2.
Table 1. The results of the $\mathrm{ABC}$-analysis of a group of ophthalmic medicinal products purchased by the pharmacy chain of the Novgorod region

\begin{tabular}{|c|c|c|c|}
\hline Group & $\begin{array}{c}\text { Number } \\
\text { of INN } \\
\text { per group }\end{array}$ & $\begin{array}{c}\text { Distribution } \\
\text { of INN } \\
\text { by groups, } \\
\%\end{array}$ & $\begin{array}{c}\text { Distribution } \\
\text { of Expenses } \\
\text { (turnover) } \\
\text { by groups, } \\
\%\end{array}$ \\
\hline \multicolumn{4}{|c|}{2016} \\
\hline A & 16 & 34.78 & 77.89 \\
\hline B & 12 & 26.09 & 16.79 \\
\hline C & 18 & 39.13 & 5.32 \\
\hline Total & 46 & 100.00 & 100.00 \\
\hline \multicolumn{4}{|c|}{2017} \\
\hline A & 19 & 40.43 & 79.46 \\
\hline B & 12 & 25.53 & 15,5 \\
\hline C & 16 & 34.04 & 5.04 \\
\hline Total & 47 & 100.00 & 100.00 \\
\hline \multicolumn{5}{|c|}{2018} \\
\hline A & 19 & 41.30 & 79.24 \\
\hline B & 12 & 26.09 & 15.74 \\
\hline C & 15 & 32.61 & 5.06 \\
\hline Total & 46 & 100.00 & 100.00 \\
\hline
\end{tabular}

Source: Compiled by the authors

Table 2. Results of ABC-analysis of a group of ophthalmic medicinal products purchased by a single pharmacy

\begin{tabular}{|c|c|c|c|}
\hline Group & $\begin{array}{c}\text { Number } \\
\text { of INN } \\
\text { per group }\end{array}$ & $\begin{array}{c}\text { Distribution } \\
\text { of INN } \\
\text { by groups, } \\
\%\end{array}$ & $\begin{array}{c}\text { Distribution } \\
\text { of Expenses } \\
\text { (turnover) } \\
\text { by groups, } \\
\%\end{array}$ \\
\hline \multicolumn{4}{|c|}{2016} \\
\hline A & 16 & 34.78 & 77.89 \\
\hline B & 12 & 26.09 & 16.79 \\
\hline C & 18 & 39.13 & 5.32 \\
\hline Total & 46 & 100.00 & 100.00 \\
\hline \multicolumn{4}{|c|}{2017} \\
\hline A & 19 & 40.43 & 79.46 \\
\hline B & 12 & 25.53 & 15.5 \\
\hline C & 16 & 34.04 & 5.04 \\
\hline Total & 47 & 100.00 & 100.00 \\
\hline \multicolumn{4}{|c|}{2018} \\
\hline A & 19 & 41.30 & 79.24 \\
\hline B & 12 & 26.09 & 15.74 \\
\hline C & 15 & 32.61 & 5.06 \\
\hline Total & 46 & 100.00 & 100.00 \\
\hline
\end{tabular}

Source: Compiled by the authors

Analysis data show a similar picture among MDs purchased by a single pharmacy. All groups included drugs belonging to different price categories.

Table 3 provides a comparative characteristic of ophthalmic medicinal products purchased by a pharmacy chain and a single pharmacy in the context of individual INNs. The range of ophthalmic drugs in a single pharmacy is somewhat smaller, but basically the same. 
Table 3. Comparative characteristics of ophthalmic MD purchased by a pharmacy chain and a single pharmacy

\begin{tabular}{|c|c|c|c|c|c|}
\hline INN of MD & $\begin{array}{l}\text { Present in the } \\
\text { Range of the } \\
\text { Pharmacy } \\
\text { Chain }\end{array}$ & $\begin{array}{l}\text { Present in } \\
\text { the Range } \\
\text { of a Single } \\
\text { Pharmacy }\end{array}$ & INN of MD & $\begin{array}{l}\text { Present in the } \\
\text { Range of the } \\
\text { Pharmacy } \\
\text { Chain }\end{array}$ & $\begin{array}{l}\text { Present in } \\
\text { the Range } \\
\text { of a Single } \\
\text { Pharmacy }\end{array}$ \\
\hline Sulfacetamide & + & - & Brinzolamide & + & - \\
\hline Tetrizoline & + & + & Dexamethasone & + & + \\
\hline Taurine & + & + & Cyclopentolate & + & + \\
\hline Ciprofloxacin & + & + & Tropicamide & + & - \\
\hline Latanoprost & + & - & Moxifloxacin & + & - \\
\hline Travoprost & + & - & Diclofenac & + & + \\
\hline $\begin{array}{l}\text { Adenosine + Nicotinamide } \\
+ \text { Cytochrome C }\end{array}$ & + & + & $\begin{array}{l}\text { Zinc sulfate + } \\
\text { Diphenhydramine + } \\
\text { Naphazoline }\end{array}$ & + & - \\
\hline Timolol & + & + & Olopatadin & + & - \\
\hline Dexpanthenol & + & + & Picloxidine & + & + \\
\hline $\begin{array}{l}\text { Diphenhydramine + } \\
\text { Interferon alpha-2a }\end{array}$ & - & + & $\begin{array}{l}\text { Polyadenylic and polyuredic } \\
\text { acids }\end{array}$ & + & - \\
\hline $\begin{array}{l}\text { Gramicidin C + } \\
\text { Dexamethasone + } \\
\text { Framycetin }\end{array}$ & + & + & $\begin{array}{l}\text { Dexamethasone + } \\
\text { Neomycin + Polymyxin B }\end{array}$ & + & + \\
\hline Azapentacen & + & + & Pilocarpine & + & + \\
\hline Carbomer & + & + & Erythromycin & + & + \\
\hline Brinzolamide + Timolol & + & - & Cromoglycic acid & + & + \\
\hline Tetracycline & + & + & Systein & - & + \\
\hline Phenylephrine & + & + & Methylethylpyridinol & - & + \\
\hline Betaxolol & + & + & \multirow{2}{*}{$\begin{array}{l}\text { Benzyldimethyl- } \\
\text { myristoylamino- } \\
\text { propylammonium }\end{array}$} & \multirow{2}{*}{+} & \multirow{2}{*}{-} \\
\hline Dorzolamide + Timolol & + & - & & & \\
\hline Dorzolamide & + & - & Lidocaine & - & + \\
\hline Hydrocortisone & + & + & Povidone & - & + \\
\hline Ofloxacin & + & + & Acyclovir + & + & - \\
\hline $\begin{array}{l}\text { Dexamethasone + } \\
\text { Tobramycin }\end{array}$ & + & + & $\begin{array}{l}\text { Gentamicin + } \\
\text { Dexamethasone }\end{array}$ & + & - \\
\hline Levofloxacin & + & + & Vizin pure tear & - & + \\
\hline Chloramphenicol & + & + & \multirow{2}{*}{ Antazoline + Naphazoline } & \multirow{2}{*}{-} & \multirow{2}{*}{+} \\
\hline Tobramycin & + & + & & & \\
\hline Hypromellose + Dextran & + & + & $\begin{array}{l}\text { Betamethasone + } \\
\text { Gentamicin }\end{array}$ & + & - \\
\hline Hypromellose & + & + & Norfloxacin & + & - \\
\hline
\end{tabular}

Source: Compiled by the authors

Of the 52 items listed, 14 INNs are on the VED List. Analyzing the assortment of a single pharmacy, it was revealed that the pharmacy purchases less drugs to reduce intraocular pressure, which is probably due to the fact that the pharmacy is located in an area where a large number of young families with children live, and glaucoma, as you know, people get sick in an older age.

\section{DISCUSSION}

Analysis of the range of ophthalmic drugs showed that it is based on the VED List. Therefore, drugs that fall into group $\mathrm{C}$ cannot be excluded from purchases, because it contained antibacterial drugs of the $3 \mathrm{rd}$ and 4th generations, antiallergic and antiviral drugs, as well as drugs for lowering intraocular pressure.

As a result, it is logical to conclude that managing the assortment of a pharmacy enterprise is an important resource for increasing competitiveness

Using internal category management as a tool, it was revealed that $26.42 \%$ of MD are included in the VED List, which limits the maintenance of a pricing policy focused on profit growth.

For example, promotion of the INN Moxifloxacin costing from 200 rubles and above for the package and falling into group $\mathrm{C}$, restricts the inclusion of the drug in the specified list. Indeed, in 2018, the main increase in prices was recorded for drugs that do not fall under price regulation $-4.0 \%$. The drugs included in the VED List increased in price by an average of $0.8 \%$ [17].

Pharmacies should use not only and not so much the organizational and economic mechanisms of doing this business, but take into account the social significance of the product they sell, increase the level of trust and loyalty of customers, and also use 
government support measures for organized support of socially vulnerable groups of the population [1822].

The use of category management in a pharmacy is also aimed at developing measures for managing the assortment [23].

Studying the retail segment of the Russian pharmaceutical market in 2018 , the authors noted that due to the merger of retail chains by federal companies, the number of private and independent enterprises on the pharmaceutical market is decreasing [17]. The stability of the assortment of a single pharmacy testifies to the fact that the effective assortment policy will allow it to continue to compete with pharmacy chains on the market.

At the end of 2018, the TOP-20 MDs were compiled in Russia (turnover in physical terms), in which, as before, drugs in the low-price category are in the lead. Of these, the highest growth rate was observed in Taufon medicinal drug $(+150 \%)$ [24]. The data of the author's research correlate with allRussian trends: almost all the time during the study period, INN Taurine was in group A.

\section{CONCLUSION}

Thus, the study showed that the level of competition in the regional pharmaceutical market is extremely high due to the large number of pharmacies with limited consumer demand from the population. Nevertheless, single pharmacies in the conditions of a Covid crisis and a permanent decrease in the average per capita income of the population can compete with drugstore chains for a long time and stably with a well-organized assortment policy. Of course, the range of $\mathrm{MD}$ in a single pharmacy is smaller than in a network one, this is confirmed by the example of a group of ophthalmic drugs presented in the study. However, this growth factor in the competitiveness of the pharmacy sector requires further research.

Analysis of the range of ophthalmic drugs showed that it is based on the VED List. The results of the $\mathrm{ABC}$-analysis indicate that the range of $\mathrm{MD}$ is stable throughout the study period, and also indicate that it is not impossible to exclude group $\mathrm{C}$ drugs from purchases due to their importance to the consumer.

The revealed feature of the development of the regional pharmaceutical market (its pharmacy segment) is consistently correlated with all-Russian trends and with the strategic priorities of the socioeconomic development of the regions. The interest in ensuring a sufficient level of competitiveness for the organizations of the pharmaceutical market, performing an important social function in the formation of a high level and quality of life of the Russian population, should come not only from the owners of pharmacies, but also be accompanied by serious support from the state. An effective pricing and assortment policy in the regional pharmaceutical market will contribute to an increase in the competitiveness of the pharmacy segment, which will lead to an increase in the quality of goods and services provided to the population, stabilization of prices for drugs from the VED List, as well as the opportunity to develop the pharmacy business both as a network and as a separate (single) small businesses.

\section{AUTHORS' CONTRIBUTIONS}

The authors made an equal contribution to the study: collection and analysis of material; definition of goals and objectives, research methods; formulation and scientific substantiation of conclusions, registration of key research results in the form of an article.

\section{ACKNOWLEDGMENTS}

The authors express their gratitude to the pharmaceutical organizations of the Novgorod region, which provided data for the clinical and economic analysis of the drug assortment, which made it possible to conduct this study and draw conclusions about the development of competition in the pharmacy market of the Novgorod region.

\section{REFERENCES}

[1] M. Mohammadzadeh, N. Bakhtiari, R. Safarey, T. Ghari, "Pharmaceutical industry in export marketing: a closer look at competitiveness", International Journal of Pharmaceutical and Healthcare Marketing, 2019, vol. 13(3), pp. 331345. DOI: 10.1108/IJPHM-02-2018-0011

[2] L.B. Okonenko, T.I. Okonenko, E.I. Lyapidovskaya, "The growing consolidation of pharmaceutical business", Vestnik NovGU, 2016, vol. 1(92), pp. 14-17. (In Russ.).

[3] N.S. Klunko, N.V. Sirotkina, O.M. Krasnonosova, "Strategic management in pharmaceutics development under world economic globalization transformations", Journal of Environmental Treatment Techniques, 2019, vol. 7(3), pp. 409-417.

[4] X. Liu, L. He, L. Yang, "Development and 
application status of pharmacy benefit management: A systematic review", Chinese Journal of Evidence-Based Medicine, 2019, vol. 19(5), pp. 595-601. DOI: 10.7507/16722531.201811061

[5] M. Hrydziuszko, G. Chodak, "Internet marketing in building the brand image of e-pharmacies: Case studies", In Proceedings of the 33rd International Business Information Management Association Conference, IBIMA 2019: Education Excellence and Innovation Management through Vision 20202019, pp. 4258-4268.

[6] M. Airaksinen, T. Toivo, L. Jokinen, E. Savela, S. Parkkamäki, C. Sandler, H. Kalliomäki, M. Dimitrow, "Policy and vision for community pharmacies in Finland: A roadmap towards enhanced integration and reduced costs", Pharmacy Practice, 2021, vol. 19(1), 2288, pp. 110. DOI: 10.18549/PharmPract.2021.1.2288

[7] T. Gaebert, M. Staňková, "Efficiency Development in the German Pharmaceutical Market", Acta Universitatis Agriculturae et Silviculturae Mendelianae Brunensis, 2020, vol. 68(5), pp. 877-884. DOI: 10.11118/actaun202068050877

[8] "In five years, the growth of the pharmaceutical market has shrunk by six times" [Za pyat let rost farmacevticheskogo rynka sokratilsya $\mathrm{v}$ shest raz], 2019. (In Russ.). Retrieved from https://www.rbc.ru/society/22/02/2019/5c6d752b 9a7947e3df5d59f6

[9] I.A. Toymentseva, O.N. Denisova, V.D. Chichkina, "The rational enterprise strategy development: Marketing aspect”, Lecture Notes in Networks and Systems, 2021, vol. 139, pp. 5465. DOI: 10.1007/978-3-030-53277-2_7

[10] S.-Y. Kang, G. Bai, M.J. Distefano, M.P. Socal, F. Yehia, G.F. Anderson, "Comparative approaches to drug pricing", Annual Review of Public Health, 2019, vol. 41, pp. 499-512. DOI: 10.1146/annurev-publhealth-040119-094305

[11] O.V. Proshkina, O.I. Efremova, "Methodology of forming the assortment policy of the enterprise", IIOABJ, 2019, vol. 10, pp. 89-92.

[12]B.E. Flores, D.C. Whybark, "Implementing multiple criteria ABC analysis", Journal of Operations Management, 1987, vol. 7(1-2), 7985. DOI: 10.1016/0272-6963(87)90008-8

[13] S.A. Rozhnova, O.V. Krylova, "Methodological approach based on the integration of $\mathrm{ABC}$ - and
XYZ-methods in the assortment policy of a pharmaceutical organization", Vestnik KazNMU, 2015, vol. 2, pp. 599-603. (In Russ.).

[14] "On the activities of the healthcare industry in the Novgorod region in 2015" [O deyatelnosti otrasli zdravoohraneniya Novgorodskoj oblasti v 2015 godu], 2015. (In Russ.). Retrieved from https://www.zdrav-novgorod.ru/novosti/4874-odeyatelnosti-otrasli-zdravookhraneniyanovgorodskoj-oblasti-v-2015-godu.html

[15] Official website of the Federal State Statistics Service [Federalnaya sluzhba gosudarstvennoj statistiki], 2021. (In Russ.). Retrieved from https://rosstat.gov.ru/

[16] G.A. Antropova, T.I. Okonenko, O.A. Fikhtner, V.R. Veber, O.D. Nemyatykh, "Pharmacovigilance as a tool for ensuring economic security in the Russian healthcare system", Advances in economics, business and management research (AEBMR), vol. 164, pp. 68-73. DOI: 10.2991/aebmr.k.210222.014

[17] "Pharmacy market analysis and forecast for 2019" [Analiz rynka aptek i prognoz na 2019], 2018. (In Russ.). Retrieved from https://alterainvest.ru/rus/blogi/analiz-rynkaaptek-2019/

[18] O. Pashanova, N. Lopatina, L. Lobuteva, O. Kartashova, "Managing consumer loyalty in the pharmaceutical market of a metropolis", Journal of Global Pharma Technology, 2019, vol. 11(8), pp. 58-67.

[19] J. Stravinskiene, M. Matuleviciene, R. Hopeniene, "Impact of corporate reputation dimensions on consumer trust", Engineering Economics, 2021, vol. 32(2), pp. 177-192. DOI: 10.5755/j01.ee.32.2.27548

[20]R. Miller, F. Wafula, C. A. Onoka, P. Saligram, A. Musiega, D. Ogira, I. Okpani, U. Ejughemre, S. Murthy, S. Garimella, M. Sanderson, S. Ettelt, "When technology precedes regulation: The challenges and opportunities of e-pharmacy in low-income and middle-income countries", BMJ Global Health, 2021, vol. 6(5), e005405. DOI: 10.1136/bmjgh-2021-005405

[21]E. Tebroke, "Reform of the pharmacy market: Pharmacists demand amendments" ["Apotheker fordern Nachbesserungen"], Pharmazeutische Zeitung, 2019, vol. 164(14), pp. 6-7. (In Germ.).

[22] O.A. Fikhtner, "Theoretical approaches to the development of the system of state and municipal 
governance in modern conditions", Vestnik Instituta ekonomiki i upravleniia NovGU [Vestnik of NovSU School of Economics and Law], 2018, vol. 1 (26), pp. 66-70. (In Russ.).

[23]I.F. Samoshchenkova, R.Y. Garankina, "Category management in the management of minimum assortment of the pharmaceutical organization”, Pharmacy \& Pharmacology, 2017, vol. 5(1), pp. 49-63. (In Russ.). DOI: 10.19163/2307-9266-2017-5-1-49-63

[24] "Results of 2018. Retail segment of the Russian pharmaceutical market" ["Itogi 2018 goda. Roznichnyj segment farmacevticheskogo rynka Rossii”], 2019. (In Russ.). Retrieved from https://dsm.ru/news/566/ 